\title{
COMMENTS
}

\section{Raising the Cost of Lying: Rethinking Erie for Judicial Estoppel}

\author{
Ashley S. Deeks†
}

\begin{abstract}
Ambitious or greedy litigants who have discovered the financial rewards of successful litigation may not be satisfied with a single victory. Instead, they may try to maximize their financial and nonfinancial successes by litigating a case as many times as possible, sometimes flagrantly reversing earlier positions. A court or an opposing party can invoke judicial estoppel to prevent such behavior. Judicial estoppel is an equitable doctrine of common law origin that prevents a litigant from asserting a position that is inconsistent with a position that she asserted in the same suit or in an earlier suit. ${ }^{1}$ Judicial estoppel, concerned far more with the court system than with the individual litigants, protects the integrity of the judicial process by preventing litigants from engaging in self-serving self-contradiction. ${ }^{2}$ The doctrine empow-
\end{abstract}

$\dagger$ B.A. 1993, Williams College; J.D. Candidate 1998, The University of Chicago.

1 Ryan Operations G.P. v Santiam-Midwest Lumber Co, 81 F3d 355, 358 (3d Cir 1996). The doctrine is also referred to as the doctrine of preclusion against inconsistent positions. See Guinness PLC $v$ Ward, 955 F2d 875, 899 (4th Cir 1992).

${ }^{2}$ Judicial estoppel should be distinguished from equitable and collateral estoppel on both technical and policy grounds. Collateral estoppel prevents a party from relitigating an issue that has affirmatively been decided by a court. Equitable estoppel, like judicial estoppel, prevents a party from contradicting a position taken in a prior proceeding, but unlike judicial estoppel, it focuses on the relationship between the litigants and is intended to ensure fair dealings between the parties. Therefore, equitable estoppel requires the party invoking the doctrine to have been an adverse party in a prior proceeding and to have relied on her opponent's earlier position. Edwards $v$ Aetna Life Insurance Co, 690 F2d 595, 598 (6th Cir 1982). Such limitations would not be appropriate for judicial estoppel, which is concerned with the relationship between the litigant and the judicial system. See generally Rand G. Boyers, Comment, Precluding Inconsistent Statements: The Doctrine of Judicial Estoppel, $80 \mathrm{Nw}$ U L Rev 1244, 1247-50 (1986). See also Ergo Science, Inc 
ers courts to preserve the sanctity of litigants' oaths, to avoid inconsistent judgments, to constrain litigants' manipulations of the judicial process, and to conserve judicial resources by throwing out inconsistent claims.

Although most courts agree on the purposes of judicial estoppel, not all agree on its parameters, and some courts have chosen not to adopt the doctrine at all. This disagreement creates the possibility that a federal court sitting in diversity may have to choose whether to apply its own version of judicial estoppel or the state's version. The traditional analysis mandated by Erie Railroad Co $v$ Tompkins ${ }^{3}$ does not provide a clear answer because judicial estoppel implicates concerns of the judicial system, which weighs in favor of applying the federal rule, but also affects the nature and content of the litigant's case, which weighs in favor of applying the state rule. In addition, a federal court's choice between federal and state law may determine the outcome of the litigation and therefore may encourage forum shopping. Moreover, the federal court's choice signals the weight it gives to the state court's interest in using judicial estoppel to protect and regulate the state court's own proceedings.

This Comment proposes that a federal court sitting in diversity should apply the most aggressive version of judicial estoppel available to it. That is, the federal court should apply the version of judicial estoppel that has the fewest requirements or constraints on its use. ${ }^{4}$ Thus, when the state has adopted a more aggressive version of judicial estoppel than the federal court, the federal court should apply state law. On the other hand, the federal court should apply its own version of judicial estoppel when the state court has adopted a less aggressive version, or when the state court has not adopted the doctrine at all.

Part I delineates the two different versions of judicial estoppel that federal and state courts currently apply, and discusses why some courts have rejected the doctrine entirely. Part II examines how federal courts sitting in diversity have tried to resolve whether, under Erie, they should apply the state court's version of the doctrine. Part III suggests why the courts' solu-

$v$ Martin, 73 F3d 595, 598 (5th Cir 1996) (noting that judicial estoppel precludes litigants from "playing fast and loose with the courts").

304 US 64, 78 (1938).

- See Part I, describing the three positions courts have taken on judicial estoppel. The "fast and loose" test is the most aggressive version of the doctrine since it does not require that a litigant have succeeded in her earlier position. The "success" test is less aggressive than the fast and loose test because it does require success with the earlier position. Courts that choose not to use judicial estoppel at all clearly have opted for the least aggressive application of the doctrine. 
tions ultimately are unsatisfactory and argues for a modified Erie solution that responds better to both the aims of the Erie doctrine and the goals of judicial estoppel. Part IV draws on conflict of laws doctrines governing statutes of limitations and evidentiary privileges to defend this modified Erie solution.

\section{THE DOCTRINE OF JUDICIAL ESTOPPEL}

Judicial estoppel advances several policy aims. First, courts wish to preserve the sanctity of litigants' oaths. ${ }^{5}$ In order to avoid appearing to condone the behavior of a litigant who takes her oath lightly, courts may bind parties to what they have said in judicial proceedings. This is necessary to "preserve the public confidence in the purity and efficiency of judicial proceedings." 6 Second, courts want to avoid the incongruity of inconsistent decisions between courts. ${ }^{7}$ If the court in which the first statement was made adopts the litigant's assertion " $\mathrm{X}$ " and the second court adopts her assertion "not X," one court is clearly wrong. ${ }^{8}$ Third, courts wish to avoid being misled by litigants; judicial estoppel "operates to prevent a party from insulting a court through improper use of judicial machinery." Additionally, courts employ the doctrine to prevent litigants from using the judicial system for undeserved personal gain. Judicial estoppel targets litigants who "play fast and loose" with the judicial system in an attempt to attain multiple recoveries from opponents or to sample different theories until a court finally allows recovery based on one. ${ }^{10}$

- See Konstantinidis v Chen, 626 F2d 933, 937 (DC Cir 1980), quoting Melton v Anderson, 32 Tenn App 335, 222 SW2d 666, 669 (Ct App 1948) ("The object is to safeguard the administration of justice by placing a restraint on the tendency to reckless and false swearing."); Warner v State Farm Mutual Automobile Insurance Co, 1994 Tenn App LEXIS $299, * 7$ (noting that judicial estoppel is based on public policy of upholding the sanctity of an oath).

${ }^{6}$ Konstantinidis, $626 \mathrm{~F} 2 \mathrm{~d}$ at 937.

7 See Edwards, $690 \mathrm{~F} 2 \mathrm{~d}$ at 599 ("The essential function of judicial estoppel is to prevent intentional inconsistency.").

${ }^{3}$ Astor Chauffeured Limousine Co v Runnfeldt Investment Corp, 910 F2d 1540, 1548 (7th Cir 1990). This is clearly illustrated by a common fact pattern in judicial estoppel cases. Often an employee, having asserted that she was permanently and totally disabled in order to receive disability insurance, brings a subsequent claim against her employer under the Americans with Disabilities Act (ADA), claiming that the employer discriminated against her by failing adequately to accommodate her disability. See McNemar $v$ The Disney Store, Inc, 91 F3d 610, 615-17 (3d Cir 1996). If one court were to accept that an employee was permanently and totally disabled and another court were to accept that she was not totally disabled, one court would be wrong.

${ }^{9}$ Konstantinidis, 626 F2d at 938.

${ }^{10}$ See McNemar, 91 F3d at 617-18 (judicially estopping litigant-who had been granted disability benefits on the ground that he was totally disabled-from recovering against his employer under the ADA on the ground that he was not totally disabled); Heggie $v$ Hayes, 141 Tenn 219, 208 SW 605, 607 (1919) (preventing defendant from 
Finally, courts want to minimize the misuse of judicial resources; since litigants with legitimate claims already stretch these resources, courts understandably want to reduce the number of illegitimate claims they must hear.

Although they have defined the nature of and uses for judicial estoppel in a mind-bending number of ways, federal and state courts generally agree on how the doctrine operates: it prevents litigants from making a statement in a proceeding that is inconsistent with a statement made in an earlier proceeding. ${ }^{11}$ However, this consensus breaks down when courts decide whether-and in what form-to apply the doctrine. Indeed, the courts appear consciously to leave the doctrine's boundaries vague, since "it may be advisable not to prescribe too many rules for the application of a doctrine designed to protect the integrity of the courts." ${ }^{\prime 2}$ Nevertheless, courts generally adopt one of three broad stances toward the doctrine.

\section{A. The Success Test}

Many courts, including the First, Second, Fifth, Sixth, and Seventh Circuits, ${ }^{13}$ only invoke judicial estoppel in subsequent litigation when an earlier court "adopted" an inconsistent assertion in a prior proceeding, or the litigant in some way received a benefit from her earlier position. ${ }^{14}$ This "success test" stems from the Supreme Court's only exploration of judicial estoppel over one hundred years ago. The Court stated that "where a party assumes a certain position in a legal proceeding, and succeeds in maintaining that position, he may not thereafter, simply because

\footnotetext{
"experimenting with the court").

${ }^{11}$ Ergo Science, 73 F3d at 598; United States v McCaskey, 9 F3d 368, 378 (5th Cir 1993); Patriot Cinemas, Inc v General Cinema Corp, 834 F2d 208, 212 (1st Cir 1987); East Cambridge Savings Bank v Wheeler, 422 Mass 621, 664 NE2d 446, 446-47 (1996); Perkins $v$ Perkins, 641 NYS2d 396, 397 (1996).

${ }^{12}$ Matter of Cassidy, 892 F2d 637, 642 (7th Cir 1990).

${ }^{23}$ See Brewer v Madigan, 945 F2d 449, 455 (1st Cir 1991); Axa Marine and Aviation Insurance Ltd $v$ Seajet Industries Inc, 84 F3d 622, 628 (2d Cir 1996); McCaskey, 9 F3d at 379; Teledyne Industries $v$ NLRB, 911 F2d 1214, 1218 (6th Cir 1990); Astor, 910 F2d at 1548.

${ }^{14}$ Most courts using this test agree, however, that the court or tribunal need not specifically adopt the litigant's position in its order. It is enough that the court relied on the litigant's statement in reaching its decision, that the litigant benefited from her position by inducing an opponent to surrender, or that the litigant entered into a bargain with the court based on her position. See Kale v Obuchowski, 985 F2d 360, 361-62 (7th Cir 1993) (Court treated state court approval of property settlement as sufficient benefit to apply judicial estoppel.); Patriot Cinemas, 834 F2d at 212-15 (Plaintiffs bargain with the court not to pursue its antitrust claim in return for an expedited discovery pace merited application of judicial estoppel.).
} 
his interests have changed, assume a contrary position."15 The success test is the most common version of the doctrine and is therefore often referred to as the "majority" position.

Not every court that has adopted the success test agrees on its specific requirements. For example, courts disagree on whether settlement of the prior proceeding constitutes the success necessary to invoke the doctrine.$^{16}$ Additionally, some courts have held that the statements must have occurred in actual court proceedings, while others have held that a statement in an administrative or quasi-judicial proceeding qualifies for judicial estoppel treatment. ${ }^{17}$

The success test allows courts to protect themselves when they feel that their integrity is threatened, while ensuring that the doctrine is not overused to the detriment of litigants. Courts adopting the success test note that if the litigant's first position failed to gain an advantage for the litigant, then there is no risk of inconsistent results between the first and second proceeding, and therefore no real threat to judicial integrity. ${ }^{18}$ These courts are concerned less with the appearance of inconsistency that might arise when parties flip positions than with the actual inconsistency that would arise if the litigant convinced two different courts of two contrary statements. ${ }^{19}$ Some courts have stated that judicial estoppel is a "harsh" doctrine that potentially prevents a case from proceeding on the merits and impinges on the

${ }^{15}$ Davis $v$ Wakelee, 156 US 680, 689 (1895). Many courts have cited Davis to support their use of the success test. See U.S. Philips Corp v Sears Roebuck \& Co, 55 F3d 592, 596 (Fed Cir 1995); Data General Corp v Johnson, 78 F3d 1556, 1565 (Fed Cir 1996). But other courts believe that Davis represents an example of equitable estoppel. See $E d$ wards, $690 \mathrm{~F} 2 \mathrm{~d}$ at 598 (citing Davis as an illustration of equitable estoppel); Konstantinidis, 626 F2d at 937 (same). Because Davis does not use the term "judicial estoppel," and because both privity and reliance were present in Davis, courts have not universally read Davis to mandate application of judicial estoppel generally or of the success test in particular.

${ }^{16}$ Compare Edwards, 690 F2d at 599 (Settlement does not imply judicial endorsement of a given position.), with Kale, 985 F2d at 361-62 (Favorable settlement is equivalent to winning a judgment.).

${ }^{17}$ Compare Czajkowski v City of Chicago, 810 F Supp 1428, 1435 (N D Il 1993) (invoking judicial estoppel for quasi-administrative proceedings), with Devon Industries $v$ American Medical International, Inc, 1995 US App LEXIS 20719, *5 (9th Cir) (unpublished opinion) (declining to apply judicial estoppel in non-judicial proceedings).

${ }^{18}$ See, for example, Edwards, 690 F2d at 599 (noting that absent judicial acceptance of the inconsistent position, the integrity of the judicial process is unaffected).

${ }^{29}$ See Teledyne, $911 \mathrm{~F} 2 \mathrm{~d}$ at 1218 (Although the success test "allows parties to contradict themselves in court, it threatens only the integrity of the parties, not of the court."). The Seventh Circuit phrases this concept slightly differently but reaches the same conclusion. See Astor, 910 F2d at 1548 (stating that courts should be offended not by inconsistent positions but by a litigant "winning, twice, on the basis of incompatible positions"). 
truth-seeking function of the courts. ${ }^{20}$ By requiring success, courts adopting this test seek to mitigate the doctrine's harshness by limiting it to cases in which a litigant could receive multiple court victories on inconsistent facts. ${ }^{21}$

\section{B. The Fast and Loose Test}

Another group of courts, including the Third Circuit, ${ }^{22}$ Fourth Circuit, ${ }^{23}$ and state courts in Tennessee, New Jersey, and Wyoming, ${ }^{24}$ has rejected the requirement of success and instead has focused on the intent of the party making the assertion. ${ }^{25}$

${ }^{2}$ Medicare Rentals, Inc $v$ Advanced Services, 119 NC App 767, 460 SE2d 361 (1995); Teledyne, $911 \mathrm{~F} 2 \mathrm{~d}$ at 1218.

${ }^{21}$ However, it should be noted that under the success standard, a party who lost on her earlier position still gains an advantage by asserting a contradictory statement in her second suit. While this situation is not especially troubling when new facts have come to light in the litigant's case, this advantage seems unjust when the litigant brings repeated suits until she finds out which set of facts (or which angle on those facts) will earn her a recovery. The "fast and loose" position, discussed below, attempts to stymie this advantage.

${ }^{22}$ Ryan Operations G.P. v Santiam-Midwest Lumber Co, 81 F3d 355, 361 (3d Cir 1996) ("[W]e begin by determining whether as a general rule a party must have benefitted from her prior position in order to be judicially estopped from subsequently asserting an inconsistent one. We readily conclude that the doctrine of judicial estoppel in this circuit contains no such requirement.").

${ }^{23}$ In one of its early judicial estoppel cases, the Fourth Circuit noted that the use of judicial estoppel need not necessarily be confined to instances of prior success, although it is "obviously more appropriate" in that situation. Allen v Zurich Insurance Co, 667 F2d 1162, 1167 (4th Cir 1982); John S. Clark Co v Faggert \& Frieden, PC, 65 F3d 26, 28-29 (4th Cir 1995) (determinative factor is whether party intentionally misled court to gain advantage). But see Lowery $v$ Stovall, 92 F3d 219, 223-24 (4th Cir 1996), cert denied as Lowery $v$ Redd, 117 S Ct 954 (1997) (citing Allen for the proposition that the prior inconsistent position must have been accepted by the court).

${ }^{2}$ Hicks $v$ Andrew Johnson Bank, 1990 Tenn App LEXIS 181, *6-7 (party need not prevail in first suit before judicial estoppel will be applied); North Jersey Savings and Loan v Fidelity and Deposit Co, 283 NJ Super 56, 660 A2d 1287, 1299 (1993) (estopping litigant from changing a position that was raised but not decided in the first litigation); Zwemer $v$ Production Credit Assn of Midlands, 792 P2d 245, 247 n 3 (Wyo 1990) (Judicial estoppel applies whether the position first assumed has been successful or not.); Amfac Mechanical Supply Co v Federer, 645 P2d 73, 79 (Wyo 1982) (applying judicial estoppel without inquiring into success of earlier position because litigant had "blown hot and cold"). Massachusetts has stated that it will apply judicial estoppel at least where the litigant was successful but has left open the question whether the state would apply it in the absence of success. See Fay v Federal National Mortgage Assn, 419 Mass 782, 647 NE2d 422,426 (1995).

${ }^{25}$ Two circuits have acknowledged the usefulness of the doctrine but remain undecided about which test-success or fast and loose-to adopt. The Ninth Circuit has noted that the doctrine favors the orderly administration of justice and furthers regard for the dignity of judicial proceedings, but it has not yet had to pick a test. Rissetto $v$ Plumbers and Steamfitters, 94 F3d 597, 601 (9th Cir 1996). The Eighth Circuit also acknowledges the split but has not come down firmly in favor of one test or the other. Robertson Oil Co $v$ Phillips Petroleum Co, 14 F3d 360, 369 n 11 (8th Cir 1992) (noting that the circuit has not yet had occasion to choose which test to adopt), affd, 14 F3d 373 (8th Cir 1993) (en 
These courts ask whether the party is "playing fast and loose" with the court. ${ }^{26}$ Under this test, a court should inquire whether a litigant is intentionally contradicting earlier statements in order to obtain an unfair advantage in a judicial forum. ${ }^{27}$ Additionally, a court may require that the litigant be acting in bad faith. ${ }^{28}$ The parameters of the "fast and loose test" are more vague than those of the success test; repeatedly courts have rejected formulaic applications of the doctrine and have insisted that "each case must be decided on its own particular facts and circumstances." 29

Like the "success" courts, the courts that have adopted the fast and loose test seek to avoid overuse of the doctrine. They may exempt false statements mistakenly asserted in earlier proceedings. ${ }^{30}$ They may require bad faith on the part of the litigant as part of the definition of "fast and loose."31 Or they may follow the success test courts by stretching to find consistency between two positions that appear facially contradictory. ${ }^{32}$ These exceptions permit a court to target those litigants who truly threaten the court's integrity. Thus, a court can strike an appropriate balance between its responsibility as a truth-seeking body and its need for self-protection.

banc). Compare Maitland v University of Minnesota, 43 F3d 357, 364 (8th Cir 1994) (implying that a court need only have adjudicated, not adopted, litigant's assertion), with Stoebner $v$ Meshbesher \& Spence Ltd, 1995 US App LEXIS 34444, *3-4 (8th Cir) (unpublished disposition) (implying that adoption is a requisite for judicial estoppel). See also Hoffman v First National Bank of Akron, Iowa, 99 BR 929, 935 (N D Iowa 1989) (stating that judicial estoppel applies whether the position first assumed was successful or not).

${ }^{2}$ See, for example, Patriot Cinemas, Inc v General Cinema Corp, 834 F2d 208, 212 (1st Cir 1987), quoting Scarano v Central $R$ Co, 203 F2d 510, 513 (3d Cir 1953).

"Patriot Cinemas, 834 F2d at 212.

${ }^{23}$ Ryan Operations, $81 \mathrm{~F} 3 \mathrm{~d}$ at 361 (articulating a two-part inquiry that asks whether the litigant has asserted an inconsistent position and whether the litigant did so in bad faith with an intent to play fast and loose with the court).

${ }^{2}$ McNemar v The Disney Store, Inc, 91 F3d 610, 617 (3d Cir 1996), quoting Scarano, 203 F2d at 513. See also Allen, 667 F2d at 1166-67 (stating that circumstances under which judicial estoppel may be invoked are not reducible to a general principle).

" Ryan Operations, 81 F3d at 362 (employing a fast and loose test and noting that judicial estoppel has a good faith mistake exception).

${ }^{31}$ Id at 361 (requiring that both inconsistency and bad faith be present before the court will invoke judicial estoppel).

${ }^{32}$ See Brewer v Madigan, 945 F2d 449, 455 (1st Cir 1991) (finding that appearance of inconsistency could be explained by FmHA's modification of a consent decree); Kupferschmidt $v$ Runyon, 827 F Supp 570, 574 (E D Wis 1993) (holding that a mental disability that left litigant totally disabled from work did not estop plaintiff from now proving she could perform the essential function of her job). 


\section{Rejection of the Doctrine}

The Tenth and D.C. Circuits, as well as several state courts, have rejected the doctrine of judicial estoppel entirely. ${ }^{33}$ These courts usually support their choice in two ways. First, they reason that the doctrine conflicts with the modern rules of pleading, which permit pleading in the alternative. ${ }^{34}$ Second, they point out that the doctrine prevents the determination of cases on their merits, which is especially problematic if factual circumstances have changed in the time between the two assertions. The Tenth Circuit, for example, believes that public policy can be vindicated more practicably and fairly in ways other than the "suppression of truth. ${ }^{.35}$ Indeed, the Supreme Court, speaking of another form of estoppel-res judicata-noted that "it blockades unexplored paths that may lead to truth." ${ }^{36}$

${ }^{33}$ See Southern Pacific Transportation Co v ICC, 69 F3d 583, 591 n 3 (DC Cir 1995) ("This court, however, has firmly disapproved of judicial estoppel in prior cases."); Brodie $v$ General Chemical Corp, 1996 US App LEXIS 418, *11 (10th Cir) (unpublished opinion) ("[T]his court does not recognize the principle of judicial estoppel."). Both circuits nevertheless have hinted that if they were to use the doctrine, they would apply the less aggressive success test. United States $v 49.01$ Acres of Land, 802 F2d 387, 390 (10th Cir 1986); Konstantinidis $v$ Chen, 626 F2d 933, 938 (DC Cir 1980). Louisiana, South Carolina, and the District of Columbia do not use judicial estoppel either. See Miramon $v$ Woods, 639 S2d 353, 358 (Ct App La 1994) (noting that "judicial estoppel is not applicable in Louisiana"); MacFarlane v Manly, 274 SC 392, 264 SE2d 838, 840 (1980) (permitting litigants to argue inconsistent positions across cases); Plough Inc $v$ National Academy of Sciences, 530 A2d 1152, $1159 \mathrm{n} 10$ (DC Ct App 1987) (noting that judicial estoppel has enjoyed "no vitality" in the District of Columbia).

Some state courts have ruled on the doctrine only rarely. New Hampshire and West Virginia, for instance, seem never to have used the doctrine, and Virginia, Alaska, and Hawaii have only used judicial estoppel a handful of times. See, for example, Maxey $v$ Doe, 217 Va 22, 225 SE2d 359, 361 (1976); Union Oil Co v Alaska, 804 P2d 62, 66 n 7 (Alaska 1990); Rosa v CWJ Contractors Ltd, 4 Hawaii App 210, 664 P2d 745, 751-52 (1983). It is possible to construe their relative silence on judicial estoppel as a rejection of the doctrine, or at least as an indication that these states do not find the doctrine helpful.

34 FRCP 8(e)(2). Konstantinidis, 626 F2d at 938 ("[W]e agree with the Tenth Circuit that utilization of the judicial estoppel theory would be out of harmony with [the modern rules of pleading.]") (citation omitted).

${ }^{35} 49.01$ Acres, 802 F2d at 390, citing Parkinson v California Co, 233 F2d 432, 438 (10th Cir 1956). The court did not, however, suggest other possible ways to sanction false assertions by litigants.

One commentator has hypothesized that the Tenth Circuit's hostility to the doctrine springs from its misuse in a particular case and that the Circuit appears to believe that judicial estoppel's usefulness always will be outweighed by the "overwhelming unfairness" it might cause. See Mark J. Plumer, Note, Judicial Estoppel: The Refurbishing of a Judicial Shield, 55 Geo Wash L Rev 409, 420-22 (1987). The case that spurred the Tenth Circuit's rejection of judicial estoppel was Parkinson, in which the district court had dismissed the plaintiffs complaint under judicial estoppel because his state pleadings and his federal pleadings were not consistent. The Tenth Circuit held that the plaintiffs positions were not inconsistent; one pleading merely omitted certain facts contained in the other. 233 F2d at 438.

${ }^{25}$ Brown v Felsen, 442 US 127, 132 (1979). 
Modern procedural accommodation of pleading in the alternative does not provide a sound reason to reject judicial estoppel. Federal Rule of Civil Procedure 8(e) states that a party may make as many claims or defenses as she wishes regardless of their consistency; however, Rule 8(e) applies only within a single case. The Rule does not condone alternative pleading between multiple cases. ${ }^{37}$ Several courts have explained convincingly that judicial estoppel acts to prevent inconsistency between different judicial proceedings, not the inconsistency within one judicial proceeding permitted by Rule $8(\mathrm{e})$ and state versions of that rule. $^{38}$

The second rationale for rejecting judicial estoppel-that it blocks the courts' truth-finding function-reflects a policy choice by these courts. They have decided to prioritize complete factual determinations over maximum protection from litigants' dishonesty, a decision that impacts other courts' self-protective functions in potentially deleterious ways. ${ }^{39}$

To some extent, therefore, a court choosing how-or whether-to apply judicial estoppel must decide how best to find the truth. Applying judicial estoppel will frustrate the general freedom courts afford litigants in presenting their cases, a freedom our adversarial system assumes will best reveal the truth. But the proponents of judicial estoppel believe that this freedom has its limits. Judicial estoppel may be necessary to protect the court from a litigant's dishonesty. This is not to say the courts that use judicial estoppel are blind to its potential to suppress the truth. In fact, it is clear that the "success" courts ${ }^{40}$ and the "fast and loose" courts" both try to mitigate the doctrine's "harshness." In the end, judicial estoppel can be a useful tool, if used in moderation, to advance the truth-seeking function of the courts.

${ }^{37}$ Yanez v United States, 753 F Supp 309, 312 (N D Cal 1990) (interpreting Rule 8(e) to mean that parties can plead alternate theories or claims in the same action but not in separate actions).

${ }^{*}$ See Allen v Zurich Insurance Co, 667 F2d 1162, 1167 (4th Cir 1982) (Judicial estoppel contemplates something other than the practice of advancing inconsistent claims in the same action.); AFN, Inc v Schlott, Inc, 798 F Supp 219, 227 n 12 (D NJ 1992) (distinguishing intentional self-contradiction in separate legal proceedings from the permissible practice of alternative pleading where the inconsistent claims or defenses can all be evaluated as such by the same tribunal).

${ }^{3}$ See Part III.C.

"See text accompanying notes $20-21$.

"See text accompanying notes 30-32. 


\section{JUDICIAI ESTOPPEL AND THE ERIE DOCTRINE}

Due to the disagreement among state and federal courts over judicial estoppel, a state court might apply a version of judicial estoppel that is different from the version used by a federal court sitting in the same state. For example, Wyoming and Utah use the success test, while the Tenth Circuit, which includes those states, does not use judicial estoppel at all. ${ }^{42}$ Conversely, South Carolina does not use judicial estoppel, ${ }^{43}$ although the Fourth Circuit, which includes South Carolina, uses a fast and loose test. ${ }^{44}$ Therefore, under Erie, when federal courts sitting in diversity must decide whether to apply federal or state judicial estoppel law, the courts face a choice with real consequences for litigants.

\section{A. Erie in Brief}

Generally, the Erie doctrine mandates that federal courts sitting in diversity apply the substantive law of the state, but federal rules of procedure. ${ }^{45}$ This simple rule casts a long shadow. Courts have found it difficult to weigh competing concerns about federalism, forum shopping, and the federal courts' power to establish and use their own procedural rules in diversity settings. In addition, Erie's progeny, while attempting to set forth more helpful tests, have instead created further confusion. In the absence of a clearly applicable Federal Rule of Civil Procedure or federal statute, there continues to be no satisfactory rule governing choice of law in diversity actions. ${ }^{46}$

Erie and its progeny reveal several basic interests behind this deceptively simple rule. The Erie Court focused on federalism interests and reasoned that under the Constitution, federal courts lack the power to declare substantive rules of common law in diversity cases. ${ }^{47}$ In Hanna $v$ Plumer ${ }^{48}$ and Byrd $v$ Blue Ridge

\footnotetext{
${ }^{42}$ See, for example, $D G$, JG and CW v Natrona County Dept of Family Services, 916 P2d 991, 998 (Wyo 1996); Stevensen v Goodson, 924 P2d 339, 352-53 (Utah 1996); Brodie $v$ General Chemical Corp, 1996 US App LEXIS 418, *11 (10th Cir).

4 MacFarlane, 264 SE2d at 840.

"Allen v Zurich Insurance Co, 667 F2d 1162, 1167 (4th Cir 1982).

${ }^{45}$ Erie, 304 US at 79-80. See Hanna v Plumer, 380 US 460, 465 (1965) ("The broad command of Erie ... [is that] federal courts are to apply state substantive law and federal procedural law.").

${ }^{45}$ Charles Alan Wright, Arthur R. Miller, and Edward H. Cooper, 19 Federal Practice and Procedure $\$ 4511$ at 342-43 (West 2d ed 1996).

${ }^{47}$ Erie, 304 US at 77-79.

${ }^{43} 380$ US 460 (1965).
} 
Rural Electric Cooperative, Inc ${ }^{49}$ the Supreme Court attempted to set clear guidelines for applying Erie.

In Hanna, the Court made explicit the twin policy aims of the Erie doctrine: discouraging forum shopping and avoiding inequitable administration of the laws. ${ }^{50}$ Consequently, under Hanna, a court must determine whether the difference between the federal and state versions of a rule would be relevant to the plaintiff's initial choice of a forum. ${ }^{51}$

The Byrd Court employed a balancing test that weighs the interests and policies of the competing federal and state courts. ${ }^{52}$ In the context of a decision about whether the Seventh Amendment dominated the state's choice of judge as fact-finder, the Court looked for and found "affirmative countervailing considerations" that justified deviations by federal courts from the form and mode of enforcement of state-created rights. ${ }^{53}$ In other words, when the federal interest is strong enough, the federal court may apply the federal rule. The Court also asked whether the state rule was bound up with state rights and examined the likelihood that using federal law would result in a different outcome than using state law. ${ }^{54}$

Although many cases recount the history of Erie and thus rely on parts of each of the four or five foundational cases, ${ }^{55}$ some version of the Hanna test coupled with Byrd balancing appears to dominate Erie jurisprudence. ${ }^{56}$ A district court recently articulated its conception of the "more modern" formulation of the Erie standard, noting three factors to consider: whether the decision is outcome determinative, whether the need for uniformity of the law is strong, and whether forum shopping is involved. ${ }^{57}$

\footnotetext{
456 US 525 (1958).

380 US at 468.

${ }^{81}$ See, for example, Olympic Sports Products, Inc v Universal Athletic Sales Co, 760 F2d 910, 914 (9th Cir 1985) (summarizing the proper inquiry after Hanna).

${ }^{62}$ Byrd, 356 US at 537-38. See also John Hart Ely, The Irrepressible Myth of Erie, 87 Harv L Rev 693, 696 (1974).

${ }^{53}$ Byrd, 356 US at 537.

" Id at 540.

${ }^{2}$ See, for example, Sun Oil Co $v$ Wortman, 486 US 717, $726-27$ (1988), citing Erie, Hanna, and Guaranty Trust Co v York, 326 US 99 (1945); S.A. Healy Co v Milwaukee Metropolitan Sewerage Dist, 60 F3d 305, 309 (7th Cir 1995), citing Erie, Hanna, Byrd, and Guaranty Trust.

"As Ely notes, "Hanna ... may not be Erie, but it seems to be the law." Ely, 87 Harv L Rev at 697 (cited in note 52). Guaranty Trust's test, criticized in Hanna, is perceived as overbroad. Ely, 87 Harv L Rev at 709. See also Wright, Miller, and Cooper, 19 Federal Practice and Procedure $\$ 4504$ at 50 (cited in note 46) ("Although the Hanna opinion is the Supreme Court's last doctrinally significant contribution to the Erie doctrine, the other principal cases ... cannot be disregarded.").

${ }^{77}$ Fischer \& Porter Co v Moorco International Inc, 869 F Supp 323, 326 (E D Pa 1994).
} 
Most courts today have a relatively sophisticated grasp of what an Erie analysis entails; the courts acknowledge that the substance/procedure distinction describes little more than a dichotomy with shifting boundaries. ${ }^{58}$ However, some commentators have suggested that despite all of these tests, courts continue to make ad hoc determinations about which law to apply. ${ }^{59}$

Judicial estoppel resists easy classification as either substantive or procedural. It prohibits a party from making specific arguments in her case, thus substantively affecting and defining her rights as a litigant. But the doctrine has strong procedural elements as well because it dictates and structures behavior inside the courtroom. Courts tread through a jurisprudential quagmire as they try to align their concerns about forum shopping and federalism with their conceptions of judicial estoppel. Perhaps because of the difficulty of the question, the federal courts that have faced this Erie question have failed to fully articulate their reasoning.

\section{B. Erie Choices}

Federal courts of appeals that have chosen, when sitting in diversity, to apply the state's version of judicial estoppel have rarely propounded reasons for their choice, often merely terming the doctrine "substantive." 60 There are, however, at least four justifications for choosing state law. First, a court might reason that judicial estoppel is primarily substantive because the doctrine

Other commentators have acknowledged Hanna's inadequacy, particularly when significant social policies of the state are at issue. See, for example, Jean A. Macchiaroli, Medical Malpractice Screening Panels: Proposed Model Legislation to Cure Judicial Ills, 58 Geo Wash L Rev 181, 224-38 (1990) (exploring the use of state medical malpractice screening by federal courts sitting in diversity).

${ }^{5}$ See Sun Oil, 486 US at 726 (criticizing the terms as abstract and contextual). See also Vernon $v$ Cassadaga Valley Central School District, 49 F3d 886, 892 (2d Cir 1995) (Cabranes concurring) (stating that courts should take care to avoid "talismanic application" of "substantive" and "procedural"); Mattison v Dallas Carrier Corp, 947 F2d 95, 109 (4th Cir 1991) (stating that the Erie doctrine cannot be applied merely by asking whether a rule is substantive or procedural). Nevertheless, this Comment will at times use the terms "procedural" and "substantive" as shorthand for the many factors that figure into the decision to apply federal or state law.

${ }^{53}$ See Gregory Gelfand and Howard B. Abrams, Putting Erie on the Right Track, 49 U Pitt L Rev 937, 940 (1988).

${ }^{\infty}$ See, for example, Original Appalachian Artworks, Inc v S. Diamond Associates, 44 F3d 925, 930 (11th Cir 1995), cert denied, 116 S Ct 705 (1996) ("Because this is a diversity case, the application of the doctrine of judicial estoppel is governed by state law."); In re Osborn, 24 F3d 1199, 1207 n 11 (10th Cir 1994) (finding judicial estoppel to be substantive and applying state law); Monterey Development Corp v Lawyer's Title Insurance Corp, 4 F3d 605, 608 (8th Cir 1993) ("Because this is a diversity case, we must apply the substantive law of Missouri."). 
curbs lying, promotes fair play, and constrains the content of a litigant's claim or defense. Second, a court could cite Guaranty Trust Co $v$ York for the proposition that a federal rule must yield when it would necessitate a result contrary to that obtained under the state rule. ${ }^{61}$ Of course, if Guaranty Trust were the exclusive Erie test, then all important Erie problems would be resolved in favor of state law. Third, a court might conclude that the state court in which the prior statement was made has a strong interest in preserving its own dignity and in "insur[ing] order in judicial proceedings." ${ }^{\text {22 }}$ Thus, the federalism interest originally identified in Erie favors application of state law.

Finally, states have a strong interest in insuring that they can provide their litigants with proper incentives. For example, when a state has told litigants they will be judicially estopped from asserting inconsistent positions, a federal court's decision to apply its own, more permissive version of the doctrine would undermine the incentives established by the state. Nonetheless, these explanations hardly settle the matter. Given that the invocation of judicial estoppel can dispose of a case, one might think that the courts would assess more rigorously the proper treatment of judicial estoppel.

Another group of courts, including the Third, Fourth, Sixth, and Ninth Circuits, apply their own versions of judicial estoppel rather than the versions applied in state courts. ${ }^{63}$ Fortunately, these courts provide more substantive reasoning when explaining their choice.

The courts that have decided to apply federal law have cited a strong federal interest that justifies disregarding state law. These courts have not relied on the substance/procedure distinction; ${ }^{64}$ rather, they have reasoned that, even if the doctrine is substantive, "affirmative countervailing considerations" require that federal law apply. ${ }^{65}$ Specifically, the "integrity" of the federal

c 326 US 99 (1945). However, the only time a case applying the state law of judicial estoppel cited Guaranty Trust was in a dissent. See Allen v Zurich Insurance Co, 667 F2d 1162, 1168 n 1 (4th Cir 1982) (Bryan dissenting), citing Guaranty Trust. This is the "outcome determinative" test, which strongly favors the application of state law and arguably was narrowed by the considerations promulgated in Hanna.

${ }^{62}$ Monterey, 4 F3d at 609.

* Ryan Operations G.P. v Santiam-Midwest Lumber Co, 81 F3d 355, 358 (3d Cir 1996); Edwards v Aetna Life Insurance Co, 690 F2d 595, 598 n 4 (6th Cir 1982); Allen, 667 F2d at 1167 n 4; Rissetto v Plumbers and Steamfitters, 94 F3d 597, 603-05 (9th Cir 1996).

st Although none has, a court might assert that federal law should apply because judicial estoppel is procedural. The Seventh Circuit has called the doctrine a "hybrid between substance and process." Astor Chauffeured Limousine Co $v$ Runnfeldt Investment Corp, 910 F2d 1540, 1551 (7th Cir 1990).

${ }_{6 \pi}$ Ryan Operations, 81 F3d at 358-59 n 2, citing Byrd, 356 US at 537-38; AFN, Inc $v$ 
courts are at stake ${ }^{66}$ and "a federal court's ability to protect itself from manipulation by litigants should not vary according to the law of the state in which the underlying dispute arose." ${ }^{167}$ Thus, given such "strong federal policy concerns," the Supreme Court's decision in Byrd supports the application of federal law. ${ }^{68}$ If, as these courts believe, the interests of the second court are uniquely implicated-even if only for the practical reason that the second court is the only court in a position to vindicate the general judicial interest in consistency ${ }^{69}$-then the federal version of the doctrine should trump the state's version. ${ }^{70}$

In the face of this judicial turmoil ${ }^{71}$ in which courts may feel obliged by Erie to abandon the protection of judicial estoppel because of the doctrine's substantive qualities, a re-evaluation of Erie proves useful.

\section{A MODIFIED ERIE SOLUTION}

\section{A. The Policy Behind Erie}

The Erie doctrine strives for the appropriate distribution of judicial power between federal and state courts. More specifically, Erie's foundation is built on three objectives. First, as Justice Brandeis himself stated, Erie reclaimed federalism from the grasp of Swift $v$ Tyson, ${ }^{72}$ which had prompted an era of decisions that "invaded rights . . . reserved by the Constitution to the sev-

Schlott, Inc, 798 F Supp 219, 224 n 6 (D NJ 1992). Neither court, however, spells out exactly what strong federal policy is at issue.

${ }^{66}$ Edwards, $690 \mathrm{~F} 2 \mathrm{~d}$ at $598 \mathrm{n} 4$.

${ }^{67}$ Ryan Operations, 81 F3d at 358-59 n 2.

${ }^{\infty} A F N, 798 \mathrm{~F}$ Supp at $224 \mathrm{n} 6$.

${ }^{\infty}$ See Rissetto, 94 F3d at 603-04.

${ }^{\text {ro }}$ Id at 603.

71 The Seventh Circuit has acknowledged that, in light of the Byrd balancing test, the hybrid nature of a doctrine like judicial estoppel makes the choice between federal and state law difficult. See Astor, 910 F2d at 1550-51; Rissetto, 94 F3d at 602-03 (listing contradictory cases). While several district courts within the Seventh Circuit have produced contradictory Erie decisions, the circuit has not yet had to decide which it would apply. Czajkowski, 810 F Supp at 1435 (noting that the Seventh Circuit has left open whether judicial estoppel is a substantive rule for which state law must be used in diversity). The Third and Fourth Circuits also have been inconsistent in their choices. For the Third Circuit, see Linan-Faye Construction Co v Housing Authority of Camden, 49 F3d 915, 933 (3d Cir 1995) (applying New Jersey law); Gleason v United States, 458 F2d 171, 175 (3d Cir 1972) (applying both federal and state law); and Ryan Operations, 81 F3d at 358-59 n 2 (suggesting, per Scarano v Central $R$ Co of New Jersey, 203 F2d 510 (3d Cir 1953), that federal law would apply). For the Fourth Circuit, compare Allen, 667 F2d at 1167 n 4 (applying federal law), with Dunkin' Donuts, Inc v Lavani, 1996 US App LEXIS 11870 *9-10 (4th Cir) (applying state law).

${ }^{72} 41$ US (16 Pet) 1 (1842). 
eral States."73 As Professor Ely put it, "what is not on the federal checklist" is to be left exclusively to the states. ${ }^{74}$ When federal statutes or rules do not cover the matter at issue, the courts should answer the Erie question according to the Rules of Decision Act, ${ }^{75}$ which provides that the laws of the several states shall be the rules of decision in civil actions except where the Constitution or acts of Congress otherwise provide. ${ }^{76}$ In other words, a state has a strong interest in substantive rules that govern the "primary decisions respecting human conduct" outside of the litigation, but its interest in procedural rules that merely prescribe how the court will provide the remedy is weaker. ${ }^{77}$

Second, as Hanna articulated, the Erie doctrine seeks to discourage forum shopping. ${ }^{78}$ Justice Harlan phrased the forum shopping concern slightly differently, and perhaps more pragmatically, when he referred to the "debilitating uncertainty in the planning of everyday affairs" that a potential resident defendant would face. She could not gauge the consequences of her behavior because she could not predict the applicable law if she were sued by an out-of-state plaintiff. ${ }^{79}$ This argument focuses only on plaintiff forum shopping; the Erie doctrine is not concerned with defendant forum shopping, which may arise when an out-of-state defendant removes to federal court a claim brought against her in state court.

Finally, the Erie doctrine is designed to promote the equitable administration of justice. Erie, and later Hanna, expressed concern about two types of unfairness: first, letting a nonresident plaintiff choose the governing law, and second, subjecting a defendant to different law depending on whether she is sued by an in-state or out-of-state plaintiff. ${ }^{80}$ When the difference between federal and state rules is trivial, such unfairness is absent, but when the rules differ substantially, the application of state substantive law minimizes both types of unfairness.

${ }^{23}$ Erie, 304 US at 80.

${ }^{24}$ Ely, 87 Harv L Rev at 701-02 (cited in note 52).

75. 28 USC $\$ 1652$ (1994).

${ }^{76}$ Ely, 87 Harv L Rev at 698, 707 (cited in note 52).

"Hanna, 380 US at 475 (Harlan concurring), cited in Allan R. Stein, Erie and Court Access, 100 Yale L J 1935, 1950-51 (1991).

${ }^{23}$ Erie was only concerned with federal/state forum shopping, in which a litigant would choose to bring her case in the federal forum if she thought the federal court would provide her with more favorable law than the state forum would. Gelfand and Abrams, 49 U Pitt L Rev at 954-55 (cited in note 59) (noting that the Supreme Court has never tried to restrict forum shopping between states).

${ }^{73}$ Ely, 87 Harv L Rev at 710 (cited in note 52), quoting Hanna, 380 US at 474.

${ }^{80}$ Ely, 87 Harv L Rev at 712 (cited in note 52). 
Although commentators have not agreed on which is the most important aim-or indeed if each is even an aim of Erie at all-the decision of which version of judicial estoppel to apply implicates all three policies. Since judicial estoppel is not supported by a federal statute, a federal court's choice to use the federal version of the doctrine may not give enough deference to the Rules of Decision Act. On the other hand, applying state law may frustrate a federal court's power to regulate the behavior of litigants in its courtroom. Additionally, there is an open invitation to forum shop when the doctrine applies in the state court and not in the federal court, or vice versa, both from the point of view of a wily plaintiff who plans on bringing a claim that contains new contradictions, and from the point of view of a plaintiff who suspects that her opponent will try to contradict an earlier statement. Finally, the potential for forum shopping implicates the third Erie concern over the equitable administration of justice.

\section{B. The Policy Behind Judicial Estoppel}

Judicial estoppel's most important policy function is to protect the integrity of the judicial process. Judicial estoppel implicates the integrity of both the state court and the federal court simultaneously. A few courts have pointed out that judicial estoppel safeguards the proper administration of justice by holding litigants to their sworn statements and preserves public confidence in the purity and efficiency of judicial proceedings. "[S]uch policy concerns are very significant, and the courts must be vigilant to preserve the overall integrity of the system." ${ }^{\text {"11 }} E d w a r d s v$ Aetna underlines this point, stating that the object of the rule "is to protect the judiciary, as an institution, from the perversion of judicial machinery." 82 Therefore, it is the inconsistency that might arise between any two courts, not just the courts of a single sovereign, that propels the doctrine. Moreover, while the inconsistent statements affect two courts most specifically, how these statements are handled affects the judicial process generally.

When a litigant asserts a position in federal court that is inconsistent with one she took in state court, she puts at risk the integrity of both the federal and the state courts. Several federal courts conclude otherwise, finding their own interests superior. First, they argue that they are the only courts in a position to do

\footnotetext{
${ }^{81}$ Krauss $v$ Aetna Life and Casualty, 1994 Conn Super LEXIS 2136, *3-4.

s2 690 F2d 595, 599 (6th Cir 1982).
} 
anything about the inconsistency ${ }^{83}$ Second, federal courts have evoked "strong federal policy" considerations as a basis for the doctrine, apparently concerned with a federal court's need to protect itself from manipulation by litigants. ${ }^{84}$ But the state court that embraces judicial estoppel also has an interest in protecting itself from manipulation. A litigant who takes a position in a court that applies judicial estoppel should know that she will be held to that position in the future. If she knows she will be bound, she will be more likely to behave honestly, or at least she will be unlikely to attempt to assert two contradictory statements. However, if a federal court entertains that litigant's contrary position in the future, the deterrent effect of the state court rule is undermined. In short, a court's interest in the application of judicial estoppel does not end when the litigant enters a new court.

\section{Why the Courts' Solutions Are Inadequate}

The solutions offered by the courts inadequately serve the interests either of the Erie doctrine or of judicial estoppel. Those federal courts that have chosen to apply their own versions of judicial estoppel invite plaintiff forum shopping. A plaintiff who intends to bring a claim contradicting an earlier position she has taken will choose, if possible, a forum that does not use judicial estoppel, or will choose the forum that most severely restricts the use of the doctrine. For instance, a Chapter 11 debtor who failed to disclose an indemnity claim for environmental cleanup costs as an asset in a bankruptcy proceeding ordinarily would be judicially estopped from prosecuting that claim in a subsequent proceeding. The debtor/plaintiff, however, would shop for the forum least likely to invoke judicial estoppel in order to litigate the indemnity. ${ }^{85}$ Alternatively, a plaintiff who anticipates that the defendant will assert an argument inconsistent with an earlier position, perhaps because of a history of litigation between the two, will choose to bring her suit in the forum most hostile to the assertion of inconsistent positions. The Erie doctrine was designed to discourage precisely this sort of intentional, strategic behavior.

${ }^{\approx}$ Rissetto $v$ Plumbers and Steamfitters, 94 F3d 597, 603-04 (9th Cir 1996) (conceding that the tribunal in which the litigant made the first statement could also be interested).

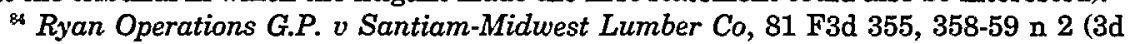
Cir 1996), quoting Byrd, 356 US at 538. See also AFN, Inc $v$ Schlott, Inc, 798 F Supp 219, 224 n 6 (D NJ 1992).

\&5e facts of this hypothetical are taken from Rosenshein $v$ Kleban, 918 F Supp 98 (S D NY 1996), and are typical of the use of judicial estoppel in post-bankruptcy proceedings. 
In addition, when federal courts employ the federal version of judicial estoppel, they encroach on federalism. The court's discussion in Ryan Operations G.P. $v$ Santiam-Midwest Lumber Co illustrates the threat to federalism: "Although I believe that judicial estoppel is substantive in nature, I am persuaded . . . that Erie does not require us to apply state law." ${ }^{186}$ It is clearly within the domain of the states to create laws to govern the behavior and responsibilities of those within their boundaries. It is equally clear that when federal courts disregard this stricture, they are expanding federal power beyond the limited powers delegated to the federal government in the Constitution. Although the federal government has expanded its powers quite vigorously throughout the twentieth century, "a general perception remains that it is desirable to maintain a certain dynamic balance between the powers of the federal government and the powers of the states, lest the states . . . disappear." ${ }^{.87}$ In Ryan Operations, Judge Sarokin overtly shoved federalism principles aside and refused to apply what he considered to be the "substantive" law of the state. This kind of act is what the Erie doctrine is intended to prevent.

Finally, a federal court that chooses to apply a less aggressive version of judicial estoppel than the state court-for example, a success test rather than a fast and loose test-denies the state court a protective device that state law provides. The state court should be allowed to erect as stringent a judicial estoppel test as it feels necessary to prevent litigants from assaulting judicial integrity. The state court should be able to bind its litigants to a restrictive version of judicial estoppel if, in the state court's opinion, doing so is the most effective way to preserve its resources and to provide the proper incentives to future litigants. To deny the state court this tool is again to flout basic principles of federalism embraced by Erie.

On the other hand, when federal courts apply the state version of judicial estoppel instead of their own, the result is equally unsatisfactory. While applying the state version avoids the perils of forum shopping, the federal courts may find themselves as unprotected as the state courts would be if the federal version were applied. If a federal court employs a fast and loose test, for example, and the state court does not use the doctrine at all, a federal court that follows the state law and thus does not apply judicial estoppel in that case loses the ability to constrain its litigants in the way it believes necessary to preserve its integrity.

\footnotetext{
${ }^{85} 81$ F3d 355, 358-59 n 2 (3d Cir 1996).

${ }^{57}$ Gelfand and Abrams, $49 \mathrm{U}$ Pitt L Rev at 951 (cited in note 59).
} 
Federal courts can no longer maintain their preferred procedures, including those that permit them to clear their dockets and maximize judicial efficiency by reducing waste. Applying the state version also reduces the federal court's ability to preserve the perception of fairness in federal proceedings.

\section{A Solution}

Since the judicial estoppel doctrine is so closely tied to the court's interests rather than the interests of any one litigant, and since the Erie tests do not argue clearly for or against the application of state or federal law, this Comment proposes a "modified Erie" solution that more precisely aligns the aims of Erie with those of judicial estoppel. The solution requires a federal court to compare the relevant state and federal versions of the doctrine, and then apply the most aggressive version. If the state has adopted a version that is more aggressive than the federal version, the state's version should be applied. If, however, the state does not use the doctrine or has adopted a version of judicial estoppel that is less aggressive than the federal version, the federal court should apply its own version of the doctrine. If neither the state nor the federal court wishes to apply the doctrine, it would not apply.

This solution partly allays federalism concerns in the face of a doctrine that can have a substantial effect on the state proceedings and that might substantially affect a "primary decision respecting human conduct." The solution also reduces forum shopping by litigants while permitting a federal court that approves of the doctrine to employ it even if the state court below would not. Finally, the solution obviates the need to define judicial estoppel as substantive or procedural, replacing that impossible task with a far easier determination of which version of the doctrine is more aggressive. In sum, this solution gives deference to state courts that aggressively utilize the doctrine without tying the hands of the federal courts.

When the state version of judicial estoppel is more aggressive than the federal version, we have a typical Erie analysis of substantive law. Because the doctrine may affect litigants' out-ofcourtroom behavior, because the use of judicial estoppel would very likely determine the outcome of the case, and because federal courts should not hear cases that a state court would not entertain, the federal court should apply the more aggressive state court version. To be sure, judicial estoppel does not as obviously

\footnotetext{
${ }^{£}$ Hanna, 380 US at 475.
} 
prevent a trial on the merits as a doctrine like collateral estoppel does. ${ }^{89}$ But it works to produce similar results. Judicial estoppel governs what arguments may be heard in the state court, and it may prevent a litigant from making an argument essential to her case. If a federal court heard that argument even though the state courts would not, then the federal court would entertain a suit effectively barred in the state courts. Erie "drastically limited the power of federal district courts to entertain suits in diversity cases that could not be brought in the respective State courts." "To Therefore, the federal court should cede to the state court's more aggressive version of judicial estoppel.

If the federal version of judicial estoppel is more aggressive than the state version, the solution's attractiveness then rests on the policy behind judicial estoppel. A court must be able to protect itself and the judicial process from abuse. To prevent a federal court from using a more aggressive form of the doctrine would allow the state to tie the hands of the federal court and to prevent the latter from developing "principles that most adequately serve [its] institutional interests." ${ }^{.91}$ Since the federal court's interests and integrity unquestionably are at stake, a federal court should be able to use a more aggressive form of judicial estoppel than the state court would. If the federal version is more aggressive, then the court unambiguously has signaled the importance of judicial estoppel and, as the court in AFN, Inc $v$ Schlott, Inc noted, this stance presents "a compelling case for an exception to Erie." ${ }^{\text {"92 }}$

The proposed solution bypasses the unending debate about judicial estoppel as substantive or procedural. It recognizes that the doctrine contains elements of both and acknowledges that the relative substantive and procedural strengths of the doctrine change depending on the content of the federal and state rules. In addition, the solution does not forsake the predictive value that a bright line rule in a typical Erie analysis can offer. In a standard Erie analysis, if a litigant knows that her state and its federal courts consider statutes of limitations substantive, she knows she should only concern herself with the state statute of limitations. Under the modified solution, a defendant who knows she can be sued only in her home state or in its respective federal

\footnotetext{
${ }^{*}$ For a comparison of judicial estoppel and collateral estoppel, see note 2 .

${ }^{90}$ Angel $v$ Bullington, 330 US 183, 192 (1947).

${ }^{91}$ Edwards, $690 \mathrm{~F} 2 \mathrm{~d}$ at $598 \mathrm{n} 4$.

${ }^{2} 798$ F Supp 219, 224 n 6 (D NJ 1992).
} 
court can quite easily determine which version of judicial estoppel is more aggressive and can adjust her behavior accordingly..$^{93}$

The modified solution is open to several criticisms. First, it assumes that a state's decision not to use judicial estoppel deserves less weight than its decision to use the doctrine. Since a court chooses to apply judicial estoppel when it concludes that the doctrine is the best way to protect itself from a certain kind of litigant misbehavior, a court that chooses not to use the doctrine may have decided that it prefers to protect itself by other means. When this is the case, and a court has decided for the sake of convenience, or because of confusion or ignorance about judicial estoppel, that Rule 11 sanctions or perjury prosecutions adequately serve to limit inconsistent statements from litigants, ${ }^{94}$ that court has little vested in its choice not to use judicial estoppel. Wright, Miller, and Cooper note that when state law is available, "it often may show nothing more than a failure to do something a federal court wants to do."95 The state law that does not use judicial estoppel may illustrate a failure to consider judicial estoppel at all; when the state's law is "created" by default, the state law should not stymie federal use of the doctrine. The state courts that have rejected the doctrine because they prefer to use alternative protections should be indifferent if federal courts wish to apply judicial estoppel.

A more powerful objection is presented by a state court that has consciously rejected judicial estoppel in order to prevent frustration of the court's truth-seeking function. ${ }^{96}$ Judicial estoppel may at times suppress the truth, and truth-seeking is an important value of the court system. ${ }^{97}$ However, for a court to reject judicial estoppel on this concern alone is for a court to be singleminded about its own function. A court's responsibility to facilitate truth-seeking should not be elevated at the expense of all

\footnotetext{
$\$ 3$ The predictive value of the solution is less clear for defendants open to suit in many states. However, this issue is beyond the scope of this Comment.

${ }^{34}$ FRCP 11. A commentator who has argued for the elimination of judicial estoppel entirely has suggested that judicial estoppel could be replaced by res judicata where there is privity and reliance, by Rule 11 sanctions, and by prosecution for perjury. See Douglas W. Henkin, Judicial Estoppel: Beating Shields into Swords-and Back Again, $139 \mathrm{U}$ Pa L Rev 1711, 1743-55 (1991).

s5 Wright, Miller, and Cooper, 19 Federal Practice \& Procedure $\$ 4513$ at 451 (cited in note 46 ).

${ }^{50}$ It is not clear that any state court actually has rejected the doctrine for this reason, although some federal courts have. See notes $35-36$ and accompanying text.

\$7 It is possible to imagine a situation in which judicial estoppel would actually enhance truth-seeking. When a court is made aware of a litigant's inconsistent statements and is considering the application of judicial estoppel, the court may examine the facts and the record surrounding the statements even more closely than it ordinarily would.
} 
other considerations, including the court's role in providing the proper incentives for people to behave well both within and outside of the judicial process. ${ }^{98}$ Evidentiary privileges illustrate this point; courts have structured the privileges to protect certain fundamental societal relationships and, given that priority, to maximize truth-seeking. ${ }^{99}$ Finally, federal courts use protective mechanisms to prevent the doctrine's misuse. Because judicial estoppel often is raised by litigants and carefully rejected by courts as inappropriate on the facts of the case, ${ }^{100}$ because the doctrine seems to have created inequities for a litigant in only a very small number of cases, and because the wide use of the doctrine bespeaks its value to courts, ${ }^{101}$ this judgment bears itself out in empirical terms. For all of these reasons, a state court decision not to use judicial estoppel out of fear of inhibiting the search for the truth should be outweighed by a federal court's desire to apply the doctrine.

Second, the modified Erie solution assumes that a state court's decision to use a less aggressive form of the doctrine, such as the success test, is less important than a federal court's decision to use a more aggressive version of the doctrine. Again, the protective mechanisms attached to judicial estoppel should mitigate the state court's concern that the doctrine will be used recklessly against its litigants once they enter federal court. More importantly, though, this assumption finds confirmation in the "affirmative countervailing considerations" of Byrd. ${ }^{102}$ Some courts and commentators have interpreted Byrd to permit application of the federal rule when the following conditions are pres-

s8 If judicial estoppel is applied according to the proposed solution, potential litigants will be on notice that they will likely be bound to their assertions made in litigation. A litigant therefore will have the correct incentive to tell the truth in the earlier proceeding if she ever intends to tell the truth. She also will have a disincentive to bring multiple suits if she made a false statement in her first suit.

${ }^{9}$ Compare University of Pennsylvania $v$ EEOC, 493 US 182, 189 (1990) (noting that courts may be justified in recognizing a privilege where that privilege "promotes sufficiently important interests to outweigh the need for probative evidence") (citation omitted), with United States $v$ Nixon, 418 US 683, 710 (1974) (holding that evidentiary privileges are "exceptions to the demand for every man's evidence" and should not be "lightly created nor expansively construed, for they are in derogation of the search for truth").

${ }^{100}$ See, for example, Medcom Holding Co $v$ Baxter Travenol Laboratories, Inc, 106 F3d 1388, 1396-97 (7th Cir 1997) (rejecting use of judicial estoppel when plaintiffs positions were not clearly inconsistent); Chrysler Credit Corp v Marino, 63 F3d 574, 580 (7th Cir 1995) (refusing to apply judicial estoppel because of context in which facts were argued); United States $v$ Garcia, 37 F3d 1359, 1366-67 (9th Cir 1994) (holding that judicial estoppel did not apply in light of defendant's overly semantic interpretation of government's statement). See also note 32 and accompanying text.

${ }^{101}$ Eleven of the thirteen circuits use judicial estoppel, as do the large majority of state courts.

${ }^{102}$ Byrd, 356 US at 537. 
ent: (1) the state rule is not "bound up" with state-created rights and obligations; (2) application of the state rule would frustrate a federal policy; and (3) the federal policy endangered by the state rule outweighs concerns that litigation will come out one way in federal court and another way in state court. ${ }^{103}$

A federal court finding the first condition could acknowledge that the doctrine affects the rights and obligations of a state's litigants, but reason that its primary effect is on the federal and state courts' powers of self-protection. The court could readily find the second condition as well-that a state's less aggressive version of the doctrine frustrates a federal court policy of discouraging inconsistent claims by litigants. Finally, the court could conclude that the weight of the federal policy is sufficient to trump a concern that the outcome of litigation would differ in federal and state court. The concern about differing outcomes reflects a fear of forum shopping, something minimized by the modified Erie solution. Byrd's "countervailing considerations" therefore cut in favor of applying the federal court's more aggressive version of the doctrine over the state's less aggressive version.

Third, once it is clear that Byrd counsels for the application of the federal court's version of judicial estoppel when that version is more aggressive, the solution also must explain why a federal court rejection of the doctrine does not reflect equally important "countervailing considerations" that recommend application of federal law. Notably, the Tenth and D.C. Circuits are the only circuits to reject the doctrine on the grounds that the doctrine frustrates truth-finding and offends public policy. ${ }^{104}$ No other circuit has asserted that the application of judicial estoppel harms a strong federal policy. In fact, the courts that have discussed federal policy concerns have argued that judicial estoppel furthers federal policy. ${ }^{105}$ This lack of widespread support for rejection of the doctrine suggests that the Tenth and D.C. Circuits, while highlighting a valid concern, have overstated the problem and exercised an excess of caution. ${ }^{106}$ If the problem with judicial estoppel is that it may inhibit full exposure of the facts, the mag-

\footnotetext{
${ }^{103}$ Wright, Miller, and Cooper, 19 Federal Practice \& Procedure $\$ 4504$ at 38 (cited in note 46) (collecting cases and commentary).

${ }^{1 / 4}$ See notes 35-36 and accompanying text.

${ }^{115}$ See $A F N$, 798 F Supp at $224 \mathrm{n} 6$ (noting that federal policy argues for the application of judicial estoppel against the defendant); Ryan Operations, 81 F3d at 358-59 n 2 (judicial estoppel furthers federal policy considerations by allowing court to protect itself).

${ }^{1 / 2}$ As noted earlier, the Tenth Circuit appears to be reacting to one particular case in which a litigant's meritorious claim was hindered by the application of judicial estoppel. See note 35 .
} 
nitude of this problem does not rise to the level of an affirmative countervailing federal interest that should overcome strong reasons for deference to a state court's affirmative use of the doctrine. ${ }^{107}$

One might also complain that the modified Erie solution does not eliminate forum shopping altogether. The solution eliminates forum shopping by plaintiffs who seek to make inconsistent statements. But it does not prevent forum shopping by a plaintiff who suspects that her opponent may assert an inconsistent statement. The latter type of plaintiff would seek the forum that would provide the most aggressive version of judicial estoppel, and the modified Erie solution ensures that the more aggressive version would be available to this plaintiff. However, from the point of view of the judiciary, this type of forum shopping is less harmful than forum shopping by a plaintiff poised with an inconsistent story and ready to "blow[ ] hot and cold" with the courts. ${ }^{108}$ In a way, this type of forum shopping enhances judicial integrity by leveraging the plaintiff's self-interest in the effort to discourage litigant inconsistencies. This escape hatch for forumshopping plaintiffs might raise concern about the inequitable administration of the laws, since the solution frustrates a defendant who relied on her ability to assert inconsistent statements. However, courts should not worry too much about treating inequitably a defendant who made a premeditated decision to assert inconsistencies.

\section{CONFLICT OF LAWS PARALLELS}

The concept behind the modified Erie solution, while unusual, is not unprecedented. ${ }^{109}$ With many Erie and conflict of

\footnotetext{
${ }^{107}$ These reasons are presented in the discussion of the modified Erie solution itself. See text accompanying notes 88-90. Similarly, federal adoption of the success test does not reflect a countervailing consideration that should defeat a state's fast and loose test. Courts adopt the success test over the fast and loose test for one of the same reasons that courts reject the doctrine entirely: the courts are concerned that, if misapplied, the doctxine may harm litigants by curtailing full fact-finding. As discussed above, this concern is not troubling enough to rise to the level of an affirmative countervailing consideration.

${ }^{108}$ Lowery $v$ Stovall, 92 F3d 219, 225 (4th Cir 1996), cert denied as Lowery $v$ Redd, 117 S Ct 954 (1997), quoting Allen, 667 F2d at 1167 n 3.

${ }^{109}$ Although this Part will compare the amended solution to how certain doctrines are handled in the conflict of laws context, the amended solution may have an additional parallel within federal/state relations. One commentator has noted that "virtually no federal court has considered itself bound by state rules that provide greater access to state courts than the federal courts have provided. In contrast, state door-closing rules have received some respect from the federal courts." Stein, 100 Yale L J at 1969-70 (cited in note 77). If a state success test compared to a federal fast and loose test can be said to be providing greater access to state courts than the federal court is providing, then the amended solution tracks the federal holdings on door-closing (that is, transfer and forum non conveni-
} 
laws issues, once a court has decided that a doctrine is to be governed by state (or federal) law, it will be governed at the categorical level by state (or federal) law regardless of the content of that law. However, when a court confronts a conflict of laws question regarding statutes of limitations or evidentiary privileges, it must look each time to the content of the competing rules in the forum and foreign courts and to the corresponding interests of each court before deciding which rule to apply. The modified Erie solution does the same thing. Despite the differences in aims that govern conflict of laws and Erie decisions, the parallels are edifying. ${ }^{110}$ This Part will describe how courts deal with statutes of limitations and evidentiary privileges in the conflicts context to demonstrate that the modified Erie solution is not unique in the law.

\section{A. Statutes of Limitations}

When a court decides whether to apply its own statute of limitations to a claim or to apply that of another state, the forum state compares the length and content of its statute of limitations to those of the other state. The proposed 1986 revisions to the Restatement (Second) of Conflict of Laws $\S 142$ provide that, when a forum court is deciding whether to apply its own statute of limitations or the statute of the original foreign state, the forum court's shorter statute of limitations applies. ${ }^{111}$ If the forum's statute of limitations is longer, "it will also apply unless there is

ens) policies.

${ }^{110}$ For example, forum shopping is permissible in the conflict of laws context. Lea Brilmayer and Ronald D. Lee, State Sovereignty and the Two Faces of Federalism: A Comparative Study of Federal Jurisdiction and the Conflict of Laws, 60 Notre Dame L Rev 833, 843 (1985). As the Supreme Court has noted, one purpose of Erie is to establish substantial uniformity of predictable outcome, whereas the purpose of adjudication in the conflict of laws context is to delimit spheres of state legislative competence. See Sun Oil Co $v$ Wortman, 486 US 717, 726-27 (1988).

There are, however, ways in which judicial estoppel and the conflict of laws treatment of statutes of limitations and evidentiary privileges address the same types of problems. All three of the doctrines acknowledge that a court does not automatically lose interest in litigation once that litigation leaves its courtroom. Both judicial estoppel and statutes of limitations balance a litigant's right to be heard with the need for efficient use of scarce judicial resources. Judicial estoppel and evidentiary privileges attempt to maximize the truth-seeking abilities of courts in light of a competing concern about protecting the integrity of the courts. Like inconsistent positions, privileged information is something that, while useful in the search for truth, would taint the proceedings. Therefore, the comparison between the modified Erie solution and the conflicts doctrines is especially appropriate; not only do the structures of the analyses mirror each other, but the reasons for performing such analyses also are similar.

${ }^{11}$ Restatement (Second) of Conflict of Laws, § 142 (1986 revisions) (Supp 1988) (proposing replacement of the original sections 142 and 143, which deemed statutes of limitations clearly procedural). 
no significant forum interest and the state having a more significant relationship to the parties and the occurrence would bar the claim."112 The current trend points toward application of the shorter statute of limitations, whether found in the forum state's law or that of the foreign state. One court has predicted that it soon will be unusual for a forum state to apply a longer statute of limitations than the foreign state would apply. "[I]t is simply a matter of time before forum states cease altogether applying their longer statutes of limitations to actions barred in the state of the center of gravity or of the most substantial contacts."113

A statute of limitations may be thought of as a continuum composed of two interests: first, the vindication of substantive claims; and second, the need to give individuals repose from stale claims and the desire to avoid adjudication of such claims. ${ }^{114}$ Comparing the length of each state's statute of limitations is a way to measure how heavily each court weighs the competing policies. When a forum court decides to apply the shorter statute of limitations of its own state, the court effectively concludes that the foreign state's interest in having the claim adjudicated is not as important as the forum state's interest in avoiding stale litigation. This is a valid conclusion since a short statute of limitations shows that the forum court, after assessing relevant factors, has decided that the importance of the litigant's right to have her claim heard fades comparatively quickly, supplanted by the court's strong self-protective interests. ${ }^{115}$ The Supreme Court has found that a forum state's use of its own shorter statute of limitations violates neither the Full Faith and Credit Clause nor due process. ${ }^{116}$ And when a forum court decides to apply the shorter foreign statute of limitations, the forum court effectively concludes that the plaintiff should be bound by the limits set by the foreign state, with whose courts, as noted in the Restatement $\S 142$, the plaintiff has a more significant relationship. ${ }^{117}$ "It follows that no court should enforce a foreign cause of action which is barred by the law governing the substantive rights of the parties." ${ }^{118}$ This resolution, too, is sensible. Where the forum state

\footnotetext{
${ }^{112}$ Eugene F. Scoles and Peter Hay, Conflict of Laws 59 (West $2 d$ ed 1992).

${ }^{123}$ Williams v Taylor Machinery, 529 S2d 606, 611 (Miss 1988) (Robertson concurring).

${ }^{14}$ Sun Oil, 486 US at 736 (Brennan concurring).

${ }^{115}$ Restatement (Second) of Conflict of Laws $\$ 142$ supports this outcome.

${ }^{116}$ Sun Oil, 486 US at 729-30. See also id at 737 (Brennan concurring), quoting Phillips Petroleum Co v Shutts, 472 US 797, 818 (1985) (For the forum state to conclude that its interest outweighs that of the claim state is "neither arbitrary nor fundamentally un-

${ }^{117}$ Restatement (Second) of Conflict of Laws, $\S 142(2)(b)$ (1986 revisions).

${ }^{118}$ Warner $v$ Auberge Gray Rocks Inn, 827 F2d 938, 941 (3d Cir 1987), quoting Ernest
} fair."). 
has a longer statute of limitations, the forum state is not overly anxious to kick the claim out of court; however, the foreign state's shorter limitation period shows that it has determined that it wants to curtail the time in which its litigants are able to file suit. By applying the foreign state's shorter statute of limitations, the forum court is yielding to the more powerful interest.

This type of analysis, in which the shorter statute of limitations applies, echoes the proposed modified Erie solution. Just as the conflicts analysis favors shorter statutes of limitations, the modified Erie analysis favors more aggressive judicial estoppel rules. The reasons for favoring the rule shift, depending on which rule the court applies. When the forum court applies its own statute of limitations, it does so to protect its own procedural, docket-clearing interest. And when the forum court applies the foreign court's statute of limitations, it does so to show respect for the foreign court's determination to bar the suit. Likewise, when the federal court uses a fast and loose test to prevent a litigant from making an inconsistent argument, the federal court's strong procedural interest trumps the state court's version. But when the state court has articulated a substantial interest in having its more aggressive version apply, the federal court, following federalism principles, shows respect for the state court's determination to bar the suit. Thus, in both situations it is appropriate to look to the content of two competing courts' rules before deciding which rule to apply. The courts abandon the futile task of categorically labelling the rule "substantive" or "procedural," acknowledging instead that the balance between vindicating a right and using judicial resources most efficiently is not static.

\section{B. Privileges}

In the conflict of laws context, evidentiary privileges offer further support for the type of analysis proposed by the modified Erie solution. Privilege rules grapple with the competing aims of aiding the search for truth and protecting certain highly valued personal and professional relationships. Courts often consider the former a procedural aim while they consider the latter a substantive aim. ${ }^{119}$ The Restatement (Second) of Conflict of Laws $\S 139$ states:

G. Lorenzen, Comment, The Statute of Limitations and the Conflict of Laws, 28 Yale L J 492, 496-98 (1919).

${ }^{19}$ Earl C. Dudley, Jr., Federalism and Federal Rule of Evidence 501: Privilege and Vertical Choice of Law, 82 Georgetown L J 1781, 1795-97 (1994). 
(1) Evidence that is not privileged under the local law of the state which has the most significant relationship with the communication will be admitted, even though it would be privileged under the local law of the forum .... (2) Evidence that is privileged under the local law of the state which has the most significant relationship with the communication but which is not privileged under the local law of the forum will [also] be admitted. ${ }^{120}$

Both parts include caveats that provide for narrow exceptions when strong public policy concerns suggest that a different outcome is more appropriate. ${ }^{121}$ But this rule clearly favors the admission of evidence, just as the modified Erie solution favors the application of judicial estoppel.

In the treatment of privileges, as in the modified Erie solution, the weight of the competing concerns shifts midstream. When the state with the most significant relationship to the communication has determined that there is no need to create a privilege, the forum court respects that decision for several reasons. ${ }^{122}$ First, the admission of the evidence actually helps the forum court in its truth-seeking function, even if the forum court would have protected similar statements made by its own litigants. Second, when the foreign state does not provide a given privilege but the forum state does, litigants should not be able to invoke a privilege that they did not rely on, in a state court in which the communication did not take place. Third, the forum court should cede to the determination by the foreign court that truth-seeking outweighs the protection of certain social relationships in that state. The state in which the communication took place decided not to protect the relationship, and therefore the choice is easy.

However, when the forum state has determined not to privilege a type of communication, and the foreign state has sought to privilege it, the choice becomes harder. Under these circumstances, to deny the privilege frustrates the foreign state's interest in protecting relationships within its borders. Yet $\S 139$ again rejects the privilege. Here, the forum state, interested in reaching correct results in litigation in its courts, "will therefore have a strong policy favoring disclosure of all relevant facts that are not privileged under its own local law." ${ }^{\text {23 }}$ The Restatement com-

\footnotetext{
${ }^{120}$ Restatement (Second) of Conflict of Laws $\S 139$ (1971).

${ }^{121}$ Id.

${ }^{122}$ Id at comment $c$.

${ }^{123}$ Id at comment $d$.
} 
mentary recognizes that the "significant relationship" state has an interest in determining whether to privilege the evidence. But the commentary nonetheless states that the forum's interests will trump unless clearly outweighed by countervailing considerations of the "significant relationship" state. ${ }^{124}$ In balancing the usefulness of privileges and the need for a forum court to be unimpeded in its search for truth in litigation before it, the Restatement weighs the balance in favor of the forum's search for truth. At least one other commentator agrees: "In some contexts, the policy embodied in a privilege rule will be weaker than some other competing policy, which may be essentially substantive in character or may relate to accuracy in fact-finding."

Section 139 thus rejects a categorical "substantive" or "procedural" labeling of privilege rules. In rejecting that treatment by looking to the substance of each state's rule and weighing the respective state's interests, Restatement $\S 139$, like the modified Erie solution, allows courts to make a more appropriate, finely tuned application of the rule.

\section{CONCLUSION}

The Erie doctrine should not force federal courts sitting in diversity to always apply the federal version of judicial estoppel or always apply the state version. The federal courts, recognizing the unique interests that judicial estoppel protects, should apply the more aggressive version, whether it be state or federal. Because this solution defers to the state version when the state has expressed greater commitment to judicial estoppel, and defers to the federal version when the federal court has more aggressively applied the doctrine, it allocates power between the two courts more evenly than a conventional Erie analysis would. The more flexible, modified approach to Erie is ideal for judicial estoppel because judicial estoppel is primarily concerned with the integrity of the courts and not the immediate interests of the litigants. This approach demonstrates a viable way to solve some Erie questions without recourse to the traditional "twin aims" or "substance or procedure" analyses. For courts dissatisfied with the traditional Erie analysis, the modified approach provides an alternative for a modest number of Erie problems. The conflict of laws treatment of statutes of limitations and of evidentiary privileges illustrates that, in other areas of the law, judges have recognized that a more content-based approach responds better

\footnotetext{
${ }^{122} \mathrm{Id}$.

${ }^{25}$ Dudley, 82 Georgetown L J at 1802 (cited in note 119).
} 
to each forum's interests. This heightened responsiveness gives power to the courts when they need it most, so that they may use judicial estoppel to maintain consistency and prevent abusive litigation within the judicial process. 